\section{CONFERENCE EVENT}

Thursday evening Watch our web site 〈http: //www.trail.com/asms/> and the spring issue of the Spectaker for details about our festive Thursday evening conference event.

\section{AWARD PRESENTATIONS AND PLENARY LECTURE}

Thursday, 7:30 PM Award presentations and plenary lecture by the recipient of the 1996 Award for Distinguished Contribution in Mass Spectrometry.

Conference participants will have a choice of hotels near the Convention Center, as well as in downtown Portland. There is a substantial number of rooms in the $\$ 60-\$ 80$ price range, as well as deluxe accommodations running $\$ 100-\$ 120$. The Portland Convention Bureau will coordinate room reservations. Portland has a light rail system which provides convenient transportation between downtown Portland and the Convention Center.

\section{Conference calendar:}

March 30 Deadline for payment of dues to obtain member registration rate for the conference and short courses

April 12 Deadline for receipt of advance registrations

May 11-12 ASMS Short Courses

May 12-16 Conference

\section{ASMS SHORT COURSES}

Five short courses will be offered Saturday and Sunday, May 11-12, immediately preceding the ASMS conference. The courses are as follows:

"Interpretation of Mass Spectra," organized by the Washington/Baltimore Mass Spectrometry Discussion Group

"LC/MS: The Art and the Practice," organized by Alfred L. Yergey and Robert D. Voyksner

"Practical MS/MS," organized by Jodie V. Johnson and Richard A. Yost

"Introduction to Ion Optics and SIMION," organized by David A. Dahl and Anthony D. Appelhans

"Mass Spectrometry-Approaches to Characterizing Peptides and Proteins," organized by Daniel B. Kassel, John Stults, and Pierre Thibault
These courses will be held at the Red Lion Hotel Lloyds Center. For additional information, contact ASMS, 1201 Don Diego Avenue, Santa Fe, NM 87505. Telephone: (505) 989-4517.

\section{RELATED EVENTS}

ASMS is happy to announce meetings of non-profit organizations. Please supply date, name of event, and location, along with the full address, telephone number and fax of contact person. You may also include a brief description, not to exceed one paragraph of 300 characters.

\section{6}

March 2-3

March 21-22

May $12-16$

March 30-April 2 ABRF '96: Biomolecular Techniques. An International Symposium sponsored by The Association of Biomolecular Resource Facilities, San Francisco, California. The conference includes symposia on new biotechnologyrelated techniques as well as numerous workshops and tutorials covering methodology related to analyses and/or synthesis of peptides, proteins, nucleic acids, and carbohydrates. Further details from Jean Lash, Meeting Manager, FASEB, 9650 Rockville Pike, Bethesda, MD 20814. Telephone (301) 530-7010. Fax: (301) 530-7014. Email: jlash@osmc.faseb.org.

44th ASMS Conference on Mass Spectrometry and Allied Topics, Oregon Convention Center, Portland, Oregon. Contact: ASMS, 1201 Don Diego Avenue, Santa $\mathrm{Fe}, \mathrm{NM}$ 87505. Telephone: (505) 989-4517. Fax: (505) 989-1073. 